\title{
PENGARUH LIKUIDITAS DAN PROFITABILITAS TERHADAP RETURN SAHAM
}

(Studi Empiris pada Perusahaan Manufaktur Sub Sektor Makanan dan Minuman di Bursa Efek Indonesia)

\author{
Siswadi Sululing ${ }^{1}$, Stefany Sandangan ${ }^{2}$ \\ Universitas Muhammadiyah Luwuk \\ ${ }^{1}$ siswadi.sululing@yahoo.com
}

\begin{abstract}
This study aims to examine the effect of current ratio and return on assets on stock returns. The dependent variable used in this study is stock returns as measured by average stock returns. While the independent variables are current ratio and return on assets. The population in this study was the food and beverage sub-sector company on the Indonesia Stock Exchange in the period of 2012-2016. The sampling technique used in this study is purposive sampling. The analysis technique used in this study was multiple linear regression analysis. The results of the analysis show that the current ratio have a negative effect on the company's stock return. While, return on assets have a positive effect on the company's stock return.
\end{abstract}

Keywords: Current Ratio, Return on Assets, Stock Return

\begin{abstract}
ABSTRAK
Penelitian ini bertujuan untuk menguji pengaruh current ratio dan return on assets terhadap return saham. Variabel dependen yang digunakan dalam penelitian ini adalah return saham yang diukur dengan return saham rata-rata. Sedangkan variabel independen adalah current ratio dan return on assets. Populasi dalam penelitian ini adalah perusahaan Sub Sektor Makanan dan Minuman di Bursa Efek Indonesia periode 2012 - 2016. Sampel dalam penelitian ini menggunakan purposive sampling. Teknik analisis yang digunakan dalam penelitian ini adalah analisis regresi linier berganda. Hasil analisis menunjukkan bahwa current ratio berpengaruh negatif terhadap return saham perusahaan. Sementara return on asset berpengaruh positif terhadap return saham perusahaan.
\end{abstract}

Kata Kunci : Current Ratio, Return on Assets, Return Saham

\section{PENDAHULUAN}

Masyarakat pada umumnya mengukur keberhasilan suatu perusahaan berdasarkan dari kinerjanya. Kinerja perusahaan dapat dinilai melalui laporan keuangan yang disajikan secara teratur setiap periode. Kondisi ini membuat persaingan semakin ketat sehingga para manajer perusahaan berusaha mencari investor untuk menginvestasikan dananya di perusahaan makanan dan minuman tersebut.

Perubahan harga saham dapat memberi petunjuk tentang kegairahan dan kelesuan aktivitas pasar modal serta pemodal dalam melakukan transaksi jual beli saham (stock). Saham telah menjadi alternatif yang menarik bagi investor untuk dijadikan sebagai objek investasi mereka dan merupakan salah satu instrumen pasar keuangan yang paling populer. 
Capital gain adalah selisih lebih harga saham pada saat menjual dan membeli saham. Deviden adalah laba yang dibagikan kepada pemegang saham. Investasi yang aman memerlukan analisis yang cermat, teliti dan didukung oleh data yang akurat sehingga dapat mengurangi risiko bagi investor dalam berinvestasi. Evaluasi kinerja keuangan merupakan salah satu alternatif bagi investor agar lebih teliti dalam mengetahui saat yang tepat untuk menjual atau membeli saham.

Pengertian laporan keuangan menurut Hanafi dan Halim (2016), yang menyatakan bahwa laporan keuangan merupakan salah satu sumber informasi yang penting disamping informasi lain seperti informasi industri, kondisi perekonomian, pangsa pasar perusahaan, kualitas manajemen dan lainnya. Menurut Sumarsan (2013) laporan keuangan merupakan hasil akhir dari siklus akuntansi yang memberikan gambaran keuangan tentang suatu perusahaan yang secara periodik disusun oleh manajemen perusahaan.

Evaluasi kinerja dapat dilakukan menggunakan analisis laporan keuangan. Dimana analisis laporan keuangan dapat dilakukan menggunakan rasio keuangan. Rasio-rasio yang digunakan untuk menilai kinerja keuangan perusahaan, seperti rasio likuiditas salah satunya rasio lancar (current ratio), dan rasio profitabilitas salah satunya marjin laba bersih (net profit margin) sering kali dijadikan tolak ukur bagi para investor dalam menentukan investasi saham.

Fahmi (2012), menyatakan return adalah keuntungan yang diperoleh oleh perusahaan, individu dan insitusi dari asil kebijakan investasi yang dilakukannya. Adapun Jogiyanto (2013), memaparkan bahwa return merupakan hasil yang diperoleh dari investasi.

Noviyanti (2017) menyimpulkan bahwa current ratio, debt to equity ratio, current ratio dan earning per share mempengaruhi return saham. Adapun Kurniawan, Yuliani, dan Ghasarma (2016) menyatakan bahwa pengaruh langsung current ratio dan debt to equity ratio tidak signifikan terhadap return saham sedangkan total asset turnover berpengaruh terhadap return saham.

Sedangkan Sululing (2014) menunjukan bahwa secara simultan current ratio, quick acid ratio, gross profit margin, net profit margin, return on equity memberikan pengaruh sebesar $12,1 \%$ terhadap return saham. Hasil penelitian secara parsial current ratio dan gross profit ratio tidak berpengaruh negatif, sedangkan quick ratio dan net profit ratio tidak berpengaruh positif terhadap return saham.

Salah satu informasi yang penting untuk diperhatikan oleh para investor saham melakukan transaksi jual beli saham adalah harga saham itu sendiri. Tingkat keuntungan perusahaan akan mempengaruhi harga saham, semakin tinggi tingkat keuntungan, maka semakin tinggi harga saham. Tujuan penelitian ini adalah: untuk menganalisis seberapa besar pengaruh current ratio dan return on assets terhadap return saham perusahaan.

\section{TINJAUAN PUSTAKA DAN PERUMUSAN HIPOTESIS Rasio Likuiditas}

Menurut Hary (2016) menyatakan bahwa rasio likuiditas adalah rasio yang menunjukkan kemampuan perusahaan dalam memenuhi kawajiban atau membayar utang jangka pendeknya. Dengan kata lain, rasio likuiditas adalah rasio yang dapat 
digunakan untuk mengukur sampai seberapa jauh tingkat kemampuan perusahaan dalam melunasi kewajiban jangka pendeknya yang akan segera jatuh tempo.

Menurut Sartono (2010), rasio likuiditas menunjukkan kemampuan untuk membayar kewajiban finansial jangka pendek tepat pada waktunya. Artinya apabila perusahaan ditagih, perusahaan akan mampu untuk memenuhi utang tersebut terutama utang yang sudah jatuh tempo."

Menurut Hary (2016, hal 50), jenis rasio likuiditas yang lazim digunakan dalam praktek untuk mengukur kemampuan perusahaan dalam memenuhi kewajiban jangka pendeknya, antara lain: rasio lancar (current ratio). Rasio lancar merupakan rasio yang digunakan untuk mengukur kemampuan perusahaan dalam memenuhi kewajiban jangka pendeknya yang segera jatuh tempo dengan menggunakan total aset lancar yang tersedia. Dengan kata lain, rasio lancar ini menggambarkan seberapa besar jumlah persediaan aset lancar yang dimiliki perusahaan dibandingkan dengan total kewajiban lancar. Oleh sebab itu, rasio lancar dihitung sebagai hasil bagi antara total aset lancar dengan total kewajiban lancar. Berikut adalah rumus yang digunakan untuk menghitung rasio lancar:

$$
\text { Rasio Lancar }=\frac{\text { Aset Lancar }}{\text { Kewajiban Lancar }}
$$

\section{Rasio Profitabilitas}

Rasio profitabilitas merupakan rasio yang digunakan untuk mengukur kemampuan perusahaan dalam menghasilkan laba dari aktivitas normal bisnisnya (Hary, 2016). Rasio profitabilitas merupakan rasio yang menggambarkan kemampuan perusahaan dalam menghasilkan laba melalui semua kemampuan dan sumber daya yang dimilikinya, yaitu yang berasal dari kegiatan penjualan dan penggunaan aset.

Menurut Hery (2016), salah satu jenis rasio profitabilitas yang lazim digunakan dalam praktek untuk mengukur kemampuan perusahaan dalam menghasilkan laba, adalah hasil pengembalian atas aset (return on asset). Hasil pengembalian atas aset merupakan rasio yang menunjukkan seberapa besar kontribusi aset dalam menciptakan laba bersih. Dengan kata lain, rasio ini digunakan untuk mengukur seberapa besar jumlah laba bersih yang akan dihasilkan dari setiap rupiah dana yang tertanam dalam total aset. Rasio ini dihitung dengan membagi laba bersih terhadap total aset.

Semakin tinggi hasil pengembalian atas aset berarti semakin tinggi pula jumlah laba bersih yang dihasilkan dari setiap rupiah dana yang tertanam dalam total aset. Sebaliknya, semakin rendah hasil pengembalian atas aset berarti semakin rendah pula jumlah laba bersih yang dihasilkan dari setiap rupiah dana yang tertanam dalam total aset. Berikut adalah rumus yang digunakan untuk menghitung hasil pengembalian atas aset:

$$
\text { Hasil Pengembalian Atas Aset }=\frac{\text { Laba Bersih }}{\text { Total Aset }}
$$

\section{Return Saham}

Menurut Jogiyanto (2009, hal. 200) menyebutkan bahwa return saham dapat diukur dengan rumus: 
Keterangan :

$$
\text { Return Saham }=\frac{\mathrm{Pt}-\mathrm{Pt}-1}{\mathrm{Pt}-1}
$$

Rt : Return saham

$\mathrm{Pt} \quad$ : Harga saham pada periode $\mathrm{t}$

$\mathrm{P}_{\mathrm{t}-1} \quad$ : Harga saham pada periode $\mathrm{t}-1$

Sedangkan menurut Jogiyanto (2013) untuk menghitung return rata - rata (average return) menggunakan rumus sebagai berikut:

$$
\mathrm{AR}=\left(\mathrm{R}_{1}+\mathrm{R}_{2}+\ldots \mathrm{R}_{\mathrm{n}}\right) / \mathrm{n}
$$

Keterangan :

AR: Average return

$\mathrm{R}_{1}:$ Return periode ke-1

$\mathrm{R}_{2}$ : Return periode ke-2

$\mathrm{R}_{\mathrm{n}}$ : Return periode ke- $\mathrm{n}$

$\mathrm{n} \quad$ : Total jumlah periode

\section{HIPOTESIS PENELITIAN}

Current ratio adalah perbandingan antara aktiva lancar (current ratios) dengan hutang lancar (current liabilities). Rasio ini menunjukkan seberapa efektif penggunaan aktiva lancar untuk membayar hutang lancar. Semakin tinggi angka rasio ini menunjukkan perusahaan mempunyai jaminan yang cukup tinggi untuk membayar hutang-hutangnya sehinggar investor berpendapat perusahaan memiliki kinerja yang baik. Hal ini akan menarik investor untuk menanamkan modalnya sehingga permintaan perusahaan saham tersebut akan meningkat. Dengan meningkatnya permintaan, maka harga saham akan meningkat. Jika harga saham saat ini meningkat, maka return saham yang diperoleh investor juga akan meningkat karena tingginya selisih antara harga saham sekarang dengan harga saham periode yang lalu. Selisih ini adalah return saham dalam bentuk capital gain. Berdasarkan uraian tersebut, maka hipotesis penelitian yang diajukan adalah:

\section{$\mathrm{H}_{1}$ : Current ratio berpengaruh terhadap return saham}

Menurut Suharli (2009), investor akan senang bila mendapat return yang semakin tinggi dari waktu ke waktu. return on assets (ROA) menghubungkan keuntugan yang diperoleh dari operasi perusahaan dengan jumlah investasi atau aktiva yang dipergunakan untuk menghasilkan keuntungan tersebut. Semakin tinggi ROA menunjukkan semakin efisien perusahaan dalam mengelola seluruh aktiva yang ada dalam perusahaan sehingga kemampuan perusahaan untuk memperoleh keuntungan semakin tinggi. Hal ini dapat menarik investor untuk membeli saham perusahaan tersebut. Dengan semakin banyak investor yang berminat terhadap saham perusahaan, membawa pengaruh terhadap meningkatnya harga saham jika harga saham saat ini meningkat maka selisih antara harga saham sekarang dengan tahun lalu semakin besar. Selisih ini adalah return saham dalam bentuk capital gain. Berdasarkan uraian tersebut, maka hipotesis penelitian yang diajukan adalah:

\section{$\mathrm{H}_{2}$ : Return on asset berpengaruh terhadap return saham}




\section{METODE PENELITAN}

\section{Populasi dan Sampel}

Populasi yang.digunakan dalam penelitian ini adalah semua perusahaan sub sektor makanan dan minuman yang listing di BEI periode 2012-2016. Metode pengambilan sampel menggunakan purposive sampling, yakni berdasarkan pertimbangan tertentu yaitu perusahaan yang menerbitkan laporan keuangan secara lengkap di BEI periode 2012-2016, laporan keuangannya telah diaudit oleh kantor akuntan yang independen, dan perusahaan yang memperoleh laba periode 2012-2016. Metode pengumpulan data yang digunakan adalah dokumentasi dengan cara mengumpulkan data sekunder dari Bursa Efek Indonesia. Sedangkan metode analisis menggunakan metode regresi linier berganda.

Jenis data yang digunakan dalam penelitian ini adalah data sekunder berupa laporan keuangan perusahaan sub sektor makanan dan minuman yang telah terdaftar di Bursa Efek Indonesia periode 2012-2016.

\section{Tabel 1. Prosedur Pengembalian sampel}

\begin{tabular}{rlcc}
\hline No. & Keterangan & Perusahaan Jumlah Data \\
\hline 1. & Perusahaan makanan \& minuman di BEI & 18 & 90 \\
2. & Perusahaan yang tidak diaudit & $(1)$ & $(5)$ \\
3. & Perusahaan yang tidak memperoleh laba & $(11)$ & $(55)$ \\
\hline & Total Sampel Penelitian Yang Digunakan & $\mathbf{6}$ & $\mathbf{3 0}$ \\
\hline
\end{tabular}

Data annual report dan data return saham diperoleh dengan mengakses secara langsung situs resmi Bursa Efek Indonesia (www.idx.co.id), dan situs resmi www.yahoo.finance.indonesia.

Penelitian ini menggunakan metode kuantitatif yaitu penelitian yang digunakan untuk meneliti populasi atau sampel tertentu dengan analisis data bersifat kuantitatif/statistik dengan tujuan untuk menguji hipotesis yang telah ditetapkan (Sugioyo, 2012:13) Penguji dapat mengidentifikasi fakta atau peristiwa kinerja return saham sebagai yang dipengaruhi (variabel dependen) dan melakukan penyelidikan mengenai variabel-variabel bebas yang mempengaruhi yaitu current ratios dan return on asset dengan menggunakan metode analisis regresi linier berganda. Gambaran tentang operasional variabel yang digunakan nampak pada Tabel 2. 
Tabel 2. Definisi Operasional Variabel Penelitian

\begin{tabular}{|c|c|c|c|c|}
\hline No. & $\begin{array}{l}\text { Variabel dan } \\
\text { Dimensi }\end{array}$ & $\begin{array}{l}\text { Konsep } \\
\text { Variabel } \\
\end{array}$ & $\begin{array}{l}\text { Indikator } \\
\text { Variabel }\end{array}$ & $\begin{array}{l}\text { Skala } \\
\text { Pengukuran }\end{array}$ \\
\hline 1. C & $\begin{array}{l}\text { Current ratio }(\mathrm{CR}) \\
\qquad\left(\mathrm{X}_{1}\right)\end{array}$ & $\begin{array}{l}\text { CR merupakan rasio } \\
\text { yang digunakan } \\
\text { untuk mengukur } \\
\text { kemampuan } \\
\text { perusahaan dalam } \\
\text { memenuhi } \\
\text { kewajiban jangka } \\
\text { pendeknya yang } \\
\text { segera jatuh tempo } \\
\text { dengan } \\
\text { menggunakan } \\
\text { aset lancarnya. }\end{array}$ & $\begin{array}{l}\text { Current ratio= } \\
\text { Aset lancar / } \\
\text { Kewajiban lancar }\end{array}$ & Rasio \\
\hline & $\begin{array}{l}\text { Return on assets } \\
(\mathrm{ROA})\left(\mathrm{X}_{2}\right)\end{array}$ & $\begin{array}{l}\text { ROA merupakan } \\
\text { rasio yang } \\
\text { menunjukkan } \\
\text { seberapa besar } \\
\text { kontribusi aset } \\
\text { dalam menciptakan } \\
\text { laba bersih }\end{array}$ & $\begin{array}{l}\text { Hasil pengembalian } \\
\text { atas aset = } \\
\text { Laba bersih / } \\
\text { Total aset }\end{array}$ & Rasio \\
\hline \multicolumn{2}{|r|}{ 3. Return saham (Y) } & $\begin{array}{l}\text { Return merupakan } \\
\text { tingkat keuntungan } \\
\text { yang dinikmati oleh } \\
\text { investor atas } \\
\text { investasi yang } \\
\text { dilakukan. } \\
\text { Mengukur return } \\
\text { saham } \\
\text { menggunakan } \\
\text { rata-rata return } \\
\text { (average return) }\end{array}$ & $\begin{array}{l}\text { Rata-rata } \\
\text { return }= \\
\mathrm{AR}= \\
\left(\mathrm{R}_{1}+\mathrm{R}_{2}+\ldots \mathrm{Rn}\right) / \mathrm{n}\end{array}$ & Rasio \\
\hline
\end{tabular}

\section{HASIL PENELITIAN DAN PEMBAHASAN}

\section{Gambaran Umum Sampel Penelitian}

Penelitian ini menggunakan sampel seluruh perusahaan sub sektor makanan dan minuman yang terdaftar di Bursa Efek Indonesia yang menerbitkan laporan keuangan periode 2012-2016. Berdasarkan kriteria-kriteria dalam purposive sampling yang telah ditetapkan sebelumnya, maka diperoleh sampel perusahaan adalah: PT. Delta Djakarta, Tbk, PT.Indofood CBP Sukses Makmur, Tbk, PT. Multi Bintang Indonesia, Tbk, PT 
Mayora Indah, Tbk, PT. Sekar Bumi, Tbk, dan PT. Ultra Jaya Milk Industri dan Trading Company, Tbk.

\section{Uji Asumsi Klasik}

Pengujian asumsi klasik yang dilakukan dalam penelitian ini adalah uji normalitas, autokolerasi, heteroskedastisitas dan multikolinearitas. Hasil pengujian asumsi klasik menunjukkan bahwa data yang digunakan dalam penelitian ini telah lolos pada pengujian asumsi klasik, yaitu uji normalitas, autokolerasi, heteroskedastisitas dan multikolinearitas.

\section{Hasil Analisa Regresi Berganda}

Berdasarkan hasil analisis, maka diperoleh persamaan regresi linear berganda sebagai berikut:

Tabel 2. Hasil Regresi Linear Berganda

\begin{tabular}{lrrl}
\hline Variabel & $\beta$ & P-Value & Kesimpulan \\
\hline Constant & 15688.614 & & \\
Current ratio & -0.034 & 0.013 & Berpengaruh negatif \\
Return on Assets & 0.276 & 0.044 & Berpengaruh positif \\
\hline
\end{tabular}

Sumber: Olahan data sekunder melalui SPSS

Berdasarkan hasil uji hipotesis yang terdapat pada tabel 2 hasil regresi linear berganda, maka diperoleh persamaan regresi linear berganda sebagai berikut:

$$
Y=15688,641-0,034 X_{1}+0,276 X_{2}
$$

\section{PEMBAHASAN}

\section{Pengaruh Current Ratio terhadap Return Saham.}

Dihipotesiskan current ratio berpengaruh terhadap return saham. Untuk membuktikan kebenaran dari hipotesis tersebut dilakukan pengujian dengan rumusan hipotesis statistik sebagai berikut:

$\mathrm{Ho}_{1}: \beta_{1} \leq 0$ : Tidak terdapat pengaruh current ratio terhadap return saham

$\mathrm{Ha}_{1}: \beta_{1}>0$ : Terdapat pengaruh positif current ratio terhadap return saham

Berdasarkan Tabel 2, diketahui bahwa variabel current ratio mempunyai nilai sig $0,013<0,05$, dengan nilai koefisien $-0,034$. Hal ini berarti current ratio berpengaruh negatif terhadap return saham.

Current Ratio dapat menunjukkan kemampuan perusahaan dalam membayar utang jangka pendek. Perusahaan yang memiliki nilai tinggi di Current Ratio mempunyai dampak yang positif bagi perusahaan maupun investor. Sebaliknya apabila Current Ratio menunjukan kemampuan aktiva lancar rendah dalam membayar utang mengakibatkan dampak negatif bagi perusahaan maupun investor. Hasil penelitian ini menunjukkan bahwa current ratio berpengaruh negatif terhadap return saham. Hal ini berarti bahwa perusahaan yang menjadi sampel penelitian banyak yang memiliki kemampuan membayar hutang jangka pendeh yang rendah sehingga mengakibatkan current ratio berpengaruh negatif terhadap return saham. 


\section{Pengaruh Return on Assets terhadap Return Saham}

Dihipotesiskan return on assets berpengaruh secara signifikan terhadap return saham pada perusahaan sub sektor makanan dan minuman yang terdaftar di Bursa Efek Indonesia.

Untuk membuktikan kebenaran dari hipotesis tersebut dilakukan pengujian secara parsia dengan rumusan hipotesis statistik sebagai berikut:

$\mathrm{Ho}_{2}: \beta_{2}>0$ Terdapat pengaruh return on assets $\left(\mathrm{X}_{2}\right)$ terhadap return saham $(\mathrm{Y})$. $\mathrm{Ha}_{2}: \beta_{2}<0$ Tidak terdapat pengaruh return on assets $\left(\mathrm{X}_{2}\right)$ terhadap return saham (Y).

Kriteria pengujiannya adalah menerima Ho jika $\mathrm{T}_{\text {hitung }}>\mathrm{T}_{\text {tabel. }}$ Tingkat derajat kebebasan Dk $=\mathrm{n}-\mathrm{k}=30-2=28$ dengan mengambil tarif signifikan $\alpha$ 0,05 maka diperoleh $\mathrm{t}_{\text {tabel }}=2,048$ dan $t_{\text {hitung }}=6,328$ sehingga $t_{\text {hitung }}>t_{\text {tabel }}$ atau dihasilkan nilai sig $0,000<0,05$ yang artinya return on assets berpengaruh terhadap return saham sehingga menerima $\mathrm{H}_{0}$ dan menolak $\mathrm{H}_{\mathrm{a}}$.

ROA adalah salah satu Rasio Profitabilitas yang digunakan untuk mengukur kemampuan perusahaan dari melihat laba yang berkaitan dengan penjualan, total aktiva, dan modal sendiri. Dalam penelitian ini peneliti menggunakan variabel Return on Asset, dengan alasan kemampuan perusahaan diukur dari hasil keuntungan menggunakan modal atau aset sendiri. Apabila perusahaan menghasilkan laba dengan modal sendiri akan berdampak positif bagi perusahaan maupun pemegang saham. Dampak positif tersebut diantaranya dengan hasil laba yang tinggi diperoleh dengan modal sendiri akan meningkatkan permintaan saham perusahaan serta harga saham perusahaan juga akan meningkat. Ketika harga saham meningkat maka return yang didapat juga akan meningkat. Return on equity yang tinggi juga menunjukkan bahwa perusahaan tidak bergantung pada penggunaan dana eksternal atau yang bisa disebut kreditor dan profitabilitas yang tinggi menunjukkan bahwa perusahaan mempunyai dana internal atau modal sendiri yang besar untuk menghasilkan laba yang tinggi, sehingga Return on asset berpengaruh positif terhadap return saham.

\section{KESIMPULAN}

Berdasarkan hasil analisis yang telah dilakukan mengenai pengaruh rasio likuiditas dan rasio profitabilitas terhadap return saham pada perusahaan sub sektor makanan dan minuman di BEI dapat ditarik beberapa kesimpulan, pertama current ratio berpengaruh secara negatif signifikan terhadap return saham pada perusahaan sub sektor makanan dan minuman di BEI tahun 2012 - 2016, dan kedua rasio return on assets berpengaruh secara positif dan signifikan terhadap return saham pada perusahaan sub sektor makanan dan minuman di BEI tahun 2012 - 2016.

Saran untuk penelitian selanjutnya, menambahkan variabel yang diperkirakan ada pengaruhnya terhadap return saham dan populasi lainnya yang terdapat di Indonesia yang belum dijadikan sampel dalam penelitian ini serta dapat menambah tahun pengamatan agar diketahui variasi yang terjadi pada perusahaan makanan dan minuman yang akan memberikan kontribusi hasil penelitian yang lebih tepat dan akurat di masa mendatang. Memperluas objek penelitian dan menambah tahun pengamatan yang mungkin akan mempengaruhi kemampuan perusahaan dalam menghasikan return saham. 


\section{DAFTAR PUSTAKA}

Fahmi, Irham. 2012. Pengantar Pasar Modal. Bandung : Alfabeta

Hanafi dan Halim. 2016. Analisis Laporan Keuangan. Edisi lima. Yogyakarta : UPP STIM YKPN

Hery. 2016. Financial Ratio for Business. Jakarta : PT Grasindo.

Jogiyanto. 2009. Portofolio dan Analisis Investasi. Edisi keenam. Yogyakarta : BPFEYogyakarta.

Jogiyanto. 2013. Teori portofolio dan Analisis Investasi. Edisi kedelapan. Yogyakarta : BPFE-Yogyakarta.

Noviyanti, Aida. 2017. Analisis pengaruh Likuiditas, Solvabilitas, dan Profitabilitas Terhadap Return Saham Perusahaan Manufaktur. Jurnal Ilmu dan Riset Manajemen, Sekolah Tinggi Ilmu Ekonomi Indonesia (STIESIA) Surabaya. Vol. 6 No.9, September 2017.

Sugiyono. 2012. Metode Penelitian Pendididkan (Pendekatan Kuantitatif, Kualitatif, dan R\&D). Bandung : Alfabeta.

Suharli, Michell. 2005. Studi Empiris Terhadap Dua Faktor Yang Mempengaruhi Return Saham Pada Industri Food and Beverage di Bursa Efek Jakarta. Jurnal Akuntansi dan Keuangan. Vol. 7, No. 2. Hal. 99-116

Sululing, Siswadi. 2014. Analisis Pengaruh Rasio Likuiditas dan Rasio Profitabiltas Terhadap Return Saham Pada Perusahaan Makanan dan Minuman Di Bursa Efek Indonesia. Jurnal Ilmiah Mutiara Muhammadiyah, Lembaga Penelitian dan Pengembangan Universitas Muhammadiyah Luwuk. Vol. 1 No. 4, Januari 2014.

Sumarsan, Thomas. 2013. Pengertian Pajak. Edisi Tiga. Jakarta : Indeks.

www.idx.co.id tentang Pengembalian sumber data perusahaan yang tercatat di sub sektor makanan dan minuman periode 2012 - 2016.

www.yahoofinance.com tentang Pengembalian harga saham yan terjadi selama periode $2012-2016$. 